\title{
Genetic analysis of the role of human U1 snRNA in mRNA splicing: I. Effect of mutations in the highly conserved stem-loop I of U1
}

\author{
Chung-Yee Yuo and Alan M. Weiner ${ }^{1}$ \\ Department of Molecular Biophysics and Biochemistry, Yale University School of Medicine, New Haven, Connecticut 06510 \\ USA
}

\begin{abstract}
The $5^{\prime}$ splice site mutation known as hr440 can be suppressed efficiently in vivo by a compensatory base change in U1 small nuclear RNA (snRNA). We have now begun a second-site reversion analysis of this suppressor U14u snRNA (which has a $C \rightarrow U$ change at position 4 ) to identify $U 1$ nucleotides that are essential for mRNA splicing. Point mutations in U1-4u that disrupt the structure of stem-loop I or alter phylogenetically conserved nucleotides within the loop cause loss of suppression. The level of suppressor activity observed for most mutants correlated with the abundance of the corresponding suppressor RNA, suggesting that mutations in stem-loop I cause loss of suppression by destabilizing U1 snRNA or the U1 snRNP (small nuclear ribonucleoprotein particle). We favor the interpretation that incompletely or improperly assembled U1 snRNPs are unstable, because two severe point mutations in stem-loop I were found to decrease the binding of U1 SnRNP-specific proteins in vitro. In a separate set of experiments, we found that increasing the distance between stem-loop I and the $5^{\prime}$ end of U1 snRNA also inhibited suppression but did not affect assembly or stability of the U1 snRNP. This suggests that the relationship between the 5 ' splice site and the body of the U1 snRNP is important for mRNA splicing.
\end{abstract}

[Key Words: Ul snRNA; mRNA splicing; snRNP assembly]

Received January 9, 1989; revised version accepted March 13, 1989.

Ul small nuclear RNA (snRNA) is the most abundant of the U-snRNAs found in all eukaryotic cells (Reddy and Busch 1988). Except for U6, the U-snRNAs are transcribed by RNA polymerase II and possess a unique trimethylguanosine cap structure (for review, see Dahlberg and Lund 1988). U-snRNAs exist in the nucleus as components of small nuclear ribonucleoprotein particles (snRNPs; for review, see Lührmann 1988). The protein components of the U1 snRNP can be divided into two classes: the common U-snRNP proteins $\left(\mathrm{B}^{\prime}, \mathrm{B}, \mathrm{D}, \mathrm{D}^{\prime}, \mathrm{E}\right.$, $F$, and $G)$ and the U1 snRNP-specific proteins $(70 \mathrm{~K}, \mathrm{~A}$, and $\mathrm{C}$ ). Autoimmune sera with anti-Sm specificity recognize several of the common U-snRNP proteins, whereas autoimmune sera with anti-(U1)RNP specificity recognize proteins unique to the U1 snRNP.

The splicing of mRNA precursors requires the U1, U2, U4/U6, and U5 snRNPs (for review, see Steitz et al. 1988). The snRNPs assemble onto the mRNA precursor to form a large multicomponent ribonucleoprotein complex called a spliceosome (Brody and Abelson 1985; Frendewey and Keller 1985; Grabowski et al. 1985). Splicing is then accomplished by two consecutive phos-

${ }^{1}$ Corresponding author. phoester bond transfers: First, the phosphoester bond at the $5^{\prime}$ splice site is attacked by the 2 ' hydroxyl group of the branchpoint residue, located 17-45 nucleotides upstream from the $3^{\prime}$ splice site. This cleaves the $5^{\prime}$ splice site and generates a lariat structure containing a $2^{\prime}-5^{\prime}$ phosphoester bond between the $5^{\prime}$ end of the intron and the branchpoint. Second, the $3^{\prime}$ hydroxyl of the $5^{\prime}$ exon attacks the phosphoester bond at the $3^{\prime}$ splice site. This ligates the two exons and releases the intron as a lariat, which later is debranched (for reviews, see Green 1986; Padgett et al. 1986).

One function of the snRNPs in mRNA splicing is to recognize essential sequences on the mRNA precursor. The U1 snRNP recognizes the 5' splice site (Mount et al. 1983; Black et al. 1985) in an interaction that depends, at least in part, on base-pairing between the $5^{\prime}$ end of $\mathrm{U} 1$ snRNA and the 5' splice site (Zhuang and Weiner 1986; Seraphin et al. 1988; Siliciano and Guthrie 1988). The U5 snRNP is believed to bind to the $3^{\prime}$ splice site (Chabot et al. 1985) by interacting with a $3^{\prime}$ splice-sitebinding protein (Gerke and Steitz 1986; Tazi et al. 1986). In yeast, the $\mathrm{U} 2$ snRNP recognizes the invariant branchpoint sequence UACUAAC by base-pairing (Parker et al. 1987), and current evidence suggests that the same is true in mammalian systems, although the branchpoint 
consensus PyUPuAC is much weaker (Reed and Maniatis 1988; Zhuang et al. 1989). In mammals, binding of the U2 snRNP to the branchpoint (Black et al. 1985) also requires an auxiliary factor called $\mathrm{U} 2 \mathrm{AF}$, which independently recognizes the $3^{\prime}$ splice site (Ruskin et al. 1988). In addition, interactions between U-snRNPs may help to assemble the spliceosome and to bring distant $5^{\prime}$ and $3^{\prime}$ splice sites together. Various hnRNP (heterogeneous nuclear ribonucleoprotein particle) proteins also may contribute to assembly of the spliceosome and recognition of specific sequences or RNA structures within the mRNA precursor (Swanson and Dreyfuss 1988).

Using the adenovirus ElA gene, we have shown previously that a $5^{\prime}$ splice site mutation known as hr440 can be suppressed efficiently in vivo by a compensatory base change in Ul snRNA (Zhuang and Weiner 1986). The suppressor U1 snRNA was designated U1-4u to indicate that position 4 in the Ul sequence was changed from $\mathrm{C}$ to $\mathrm{U}$ to compensate for the $\mathrm{G} \rightarrow \mathrm{A}$ change at position +5 in the $12 S 5^{\prime}$ splice site introduced by the hr440 mutation. The existence of a suppressor Ul snRNA provides a tool for a genetic analysis of the role of U1 snRNP in splicing. Second-site mutations can now be introduced into the suppressor U1 RNA to identify U1 nucleotides that are essential for function. This kind of second-site reversion analysis should enable us to identify Ul nucleotides that are involved in steps such as snRNP assembly, snRNP binding to the mRNA precursor, interaction between snRNPs within the spliceosome, and possibly the actual phosphoester bond transfers that accomplish splicing. In this initial paper we describe the characterization of point mutants in stem-loop I of the suppressor U1-4u snRNA.

\section{Results}

Construction and analysis of suppressor U1-4u secondsite mutations

To begin our genetic analysis of U1 structure and function, we chose to make point mutations in stem-loop I because both the structure of this stem and the sequence of the loop have been highly conserved through evolution (Branlant et al. 1980; Mount and Steitz 1981; Forbes et al. 1984; Kato and Harada 1985; Yu et al. 1986; Kretzner et al. 1987; Siliciano et al. 1987; van Santen and Spritz 1987; Kiss et al. 1988; van Santen et al. 1988). Figure 1 shows the location of 22 point mutations that were introduced by site-directed mutagenesis into stemloop I of the suppressor U1-4u.

To determine the suppressor activity of the U1-4u mutants, we performed a transient expression assay using the hr440 mutant of the adenovirus E1A mRNA precursor as substrate. HeLa cells were cotransfected with a mutant U1-4u gene and an E1A gene containing the hr440 mutation that abolishes $12 \mathrm{~S}$ splicing (Zhuang and Weiner 1986). Suppression of the defect in $12 \mathrm{~S}$ splicing then was measured by subjecting total cytoplasmic RNA from the transfected cells to RNase protection analysis. As shown in Figure 2, RNA from cells transfected with the hr440 gene alone and no suppressor

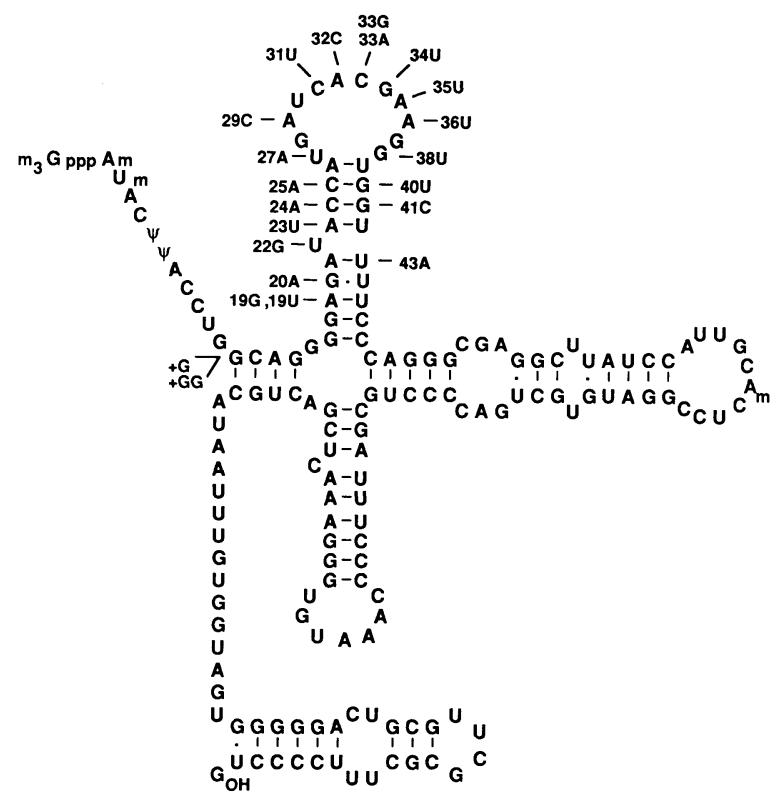

Figure 1. Second-site mutations in the suppressor $U 1-4 \mathrm{u}$ snRNA. For clarity, the proposed secondary structure (Mount and Steitz 1981) of wild-type human Ul snRNA (Branlant et al. 1980 ) is shown; in U1-4u, the C in position 4 is changed to a $U$. Point mutations within stem-loop I of U1-4u are designated by the position of the substitution, followed by the new nucleotide. Insertions of one or two $G$ residues at position 11 are indicated by $+\mathrm{G}$ and $+\mathrm{GG}$. Following the convention used for all other RNA polymerase II transcripts, we designate the first transcribed nucleotide of U1 position 1; note, however, that an alternative convention exists (e.g., Kretzner et al. 1987) in which the guanosine cap is designated position 1 for historical reasons dating back to the discovery of caps by Reddy et al. (1974).

U1-4u gene protected only two fragments derived from the $5^{\prime}$ and $3^{\prime}$ exons of E1A 13S RNA (Fig. 2A, lane 3; Fig. $2 \mathrm{~B}$, lanes 3 and 11 ; a residual level of $12 \mathrm{~S} 5^{\prime}$ exon is detected also). RNA from cells transfected with the hr440 gene, together with the suppressor $\mathrm{Ul}-4 \mathrm{u}$ gene, gave a much stronger 12S 5' exon signal (Fig 2A, lane 4; Fig. 2B, lanes 4 and 12). RNAs from cells transfected with the $\mathrm{hr} 440$ gene and different U1-4u mutants protected variable amounts of the $12 S 5^{\prime}$ exon fragment. Levels of suppression obtained with different U1-4u mutants were quantified by densitometry. To do this, we measured the level of protected $12 S 5^{\prime}$ exon fragment relative to $3^{\prime}$ exon fragment to normalize suppression to the total amount of stable $9 S+12 S+13 S$ mRNA derived from the E1A transcription unit /see Zhuang and Weiner 1986). The suppressor activities of the U1-4u mutants are shown in Table 1 as a percentage of the suppression obtained with the parental U1-4u.

\section{Disruption of stem I reduces suppression}

Mutations that disrupt base-pairing in stem I generally result in poor suppression (Table 1); this is especially true for the four mutations that disrupt base-pairing in 

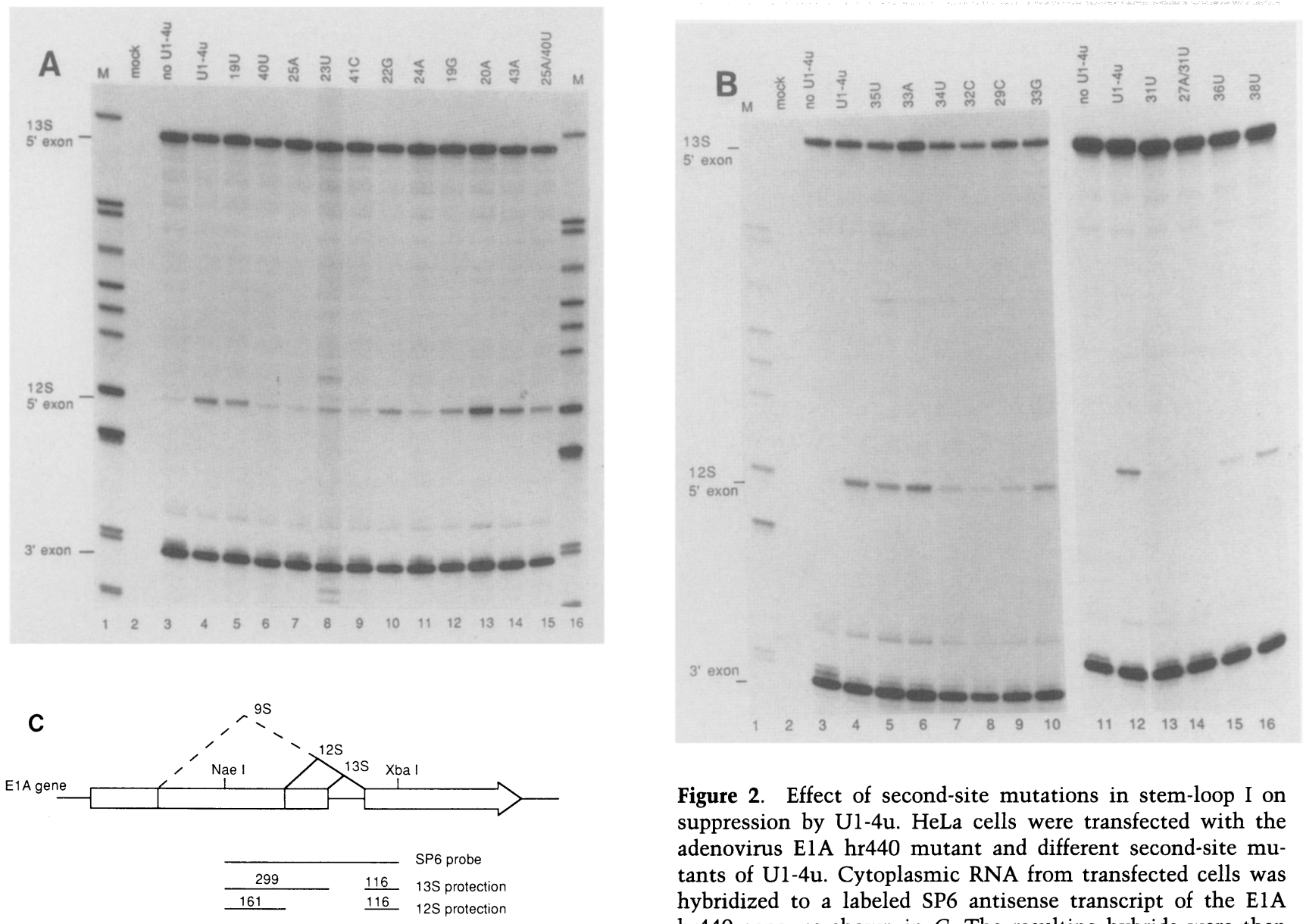

Figure 2. Effect of second-site mutations in stem-loop I on suppression by U1-4u. HeLa cells were transfected with the adenovirus ElA hr440 mutant and different second-site mutants of U1-4u. Cytoplasmic RNA from transfected cells was hybridized to a labeled SP6 antisense transcript of the E1A hr440 gene, as shown in $C$. The resulting hybrids were then

digested with $\mathrm{Tl}$ and pancreatic RNase and resolved on a 5\% denaturing polyacrylamide gel. (A) Cells were transfected with hr440 and pUC13 vector (lane 3), with hr440 and the U1-4u gene (lane 4) or with hr440 and mutants in the stem of stem-loop I of U1-4u (lanes 5-15). (Lane 2) Mock-transfected cells without added DNA; (lanes $M$ ) denatured DNA size markers from an end-labeled HpaII digest of pBR322. (B) Cells were transfected with hr440 and mutants in the loop of stem-loop I of U1-4u (lanes 5-10,13-16). Other lanes are as in $A$.

the middle of the upper stem (mutants $24 \mathrm{~A}, 25 \mathrm{~A}, 40 \mathrm{U}$, and $41 \mathrm{C}$. The compensatory double-point mutation $25 \mathrm{~A} / 40 \mathrm{U}$ was made by combining mutations $25 \mathrm{~A}$ and 40U, thereby replacing a $C: G$ with an $A: U$ base pair. Although the component point mutations $25 \mathrm{~A}$ and $40 \mathrm{U}$ are both severely defective $(7-13 \%$ suppression), the compensatory double-point mutation $25 \mathrm{~A} / 40 \mathrm{U}$ restores suppressor activity to nearly normal levels $(\sim 78 \%)$. The importance of a stable stem I is supported further by the effect of mutation $20 \mathrm{~A}$, which presumably strengthens stem I by replacing the normal G : U base pair with a stronger A : U base pair and reproducibly gives higher levels of suppression than the parental U1-4u. Mutation $43 \mathrm{~A}$ appears to disrupt base-pairing within the stem and yet has little effect on suppression. Superficially, this result would appear to contradict the idea that U1 function requires a stable stem $I_{\text {; }}$ however, it is also possible that $A_{43}$ base-pairs with $U_{22}$, restoring the stable stem and bulging $A_{21}$ instead of $U_{22}$. Consistent with the interpretation that the identity of the bulged nucleotide in stem I is not critical, mutation $22 \mathrm{G}$ replaces the bulged
$\mathrm{U}$ residue with a $\mathrm{G}$ but does not seriously impair suppression ( $85 \%$ suppression). From these results, we conclude that a stable stem I structure is essential for U1 snRNA to function in splicing.

\section{Loop I mutations have a wide range of phenotypes}

Mutations in loop I yield a range of phenotypes from normal to null (Fig. 2B). As expected, mutation of the phylogenetically conserved $\mathrm{C}_{31}$ (see Table 2) almost completely abolishes suppression (mutant $31 \mathrm{U}$ ), but mutation of the unconserved $\mathrm{C}_{33}$ has little effect; mutant 33A has wild-type suppressor activity, and 33G has $\sim 86 \%$ activity. Mutations in other highly conserved loop nucleotides, however, have only intermediate effects (29C, 32C, 34U, 35U, 36U, and 38U). Perhaps even more surprising is the observation that duplication of the highly conserved nucleotides 28-31 does not abolish suppression (mutant $\mathrm{r} 28-31$; 19\% residual suppressor activity). Mutation $38 \mathrm{U}$, which might have been expected to disrupt a potential $U_{27}: G_{38}$ base pair at the 
Table 1. Suppressor activities and cellular abundances of the U1-4u mutants

\begin{tabular}{|c|c|c|c|c|c|}
\hline \multirow[b]{2}{*}{ Mutant } & \multicolumn{4}{|c|}{ Suppressor activity $(\%)^{a}$} & \multirow[b]{2}{*}{ Abundance $(\%)^{t}$} \\
\hline & exp. 1 & exp. 2 & exp. 3 & $\overline{\text { average }}$ & \\
\hline \multicolumn{6}{|c|}{ Stem mutants } \\
\hline $25 \mathrm{~A}$ & 10 & 4 & & 7 & 15 \\
\hline $40 U$ & 11 & 14 & & 13 & 20 \\
\hline $41 \mathrm{C}$ & 22 & 15 & & 19 & 32 \\
\hline $24 \mathrm{~A}$ & 27 & 13 & & 20 & 34 \\
\hline $23 \mathrm{U}$ & 43 & 39 & & 41 & ND \\
\hline $19 \mathrm{U}$ & 41 & 47 & & 44 & ND \\
\hline $19 \mathrm{G}$ & 65 & 57 & & 61 & ND \\
\hline $25 \mathrm{~A} / 40 \mathrm{U}$ & ND & 78 & & 78 & 151 \\
\hline $22 \mathrm{G}$ & 92 & 77 & & 85 & ND \\
\hline $43 \mathrm{~A}$ & 64 & 109 & & 87 & 88 \\
\hline $20 \mathrm{~A}$ & 114 & 143 & & 129 & ND \\
\hline \multicolumn{6}{|c|}{ Loop mutants } \\
\hline $27 \mathrm{~A} / 31 \mathrm{U}$ & 1 & 0 & 0 & 0 & ND \\
\hline $31 \mathrm{U}$ & 2 & 0 & 0 & 1 & 8 \\
\hline $\mathrm{r} 28-31$ & ND & 22 & 15 & 19 & 25 \\
\hline $36 \mathrm{U}$ & 25 & 43 & 27 & 32 & 33 \\
\hline $32 \mathrm{C}$ & 57 & 51 & 31 & 46 & 60 \\
\hline $29 \mathrm{C}$ & 56 & 56 & 35 & 49 & 45 \\
\hline $34 \mathrm{U}$ & 62 & 69 & 38 & 56 & ND \\
\hline $38 \mathrm{U}$ & 66 & 70 & 43 & 60 & ND \\
\hline $35 \mathrm{U}$ & 52 & 85 & 67 & 68 & ND \\
\hline $33 \mathrm{G}$ & 95 & 99 & 65 & 86 & ND \\
\hline $33 \mathrm{~A}$ & 100 & 133 & 92 & 108 & 122 \\
\hline \multicolumn{6}{|c|}{ Insertion mutants } \\
\hline$+\mathrm{G}$ & 34 & 34 & & 34 & ND \\
\hline$+\mathrm{GG}$ & 29 & 19 & & 24 & 105 \\
\hline
\end{tabular}

a Percent relative to U1-4u.

b The abundance of stem and loop mutants was determined by densitometry of the autoradiogram shown in Fig. 3. Percentages are relative to U1-4u. The abundance of the +GG insertion mutant was determined by densitometry of the autoradiogram shown in Fig. 6. Due to proximity of the $+G$ and wild-type $U 1$ bands, the abundance of the $+G$ mutant could not be quantified by densitometry; however, visual comparison of two different exposures of the gel shown in Fig. 6 suggest that the $+G$ and + GG mutants are equally abundant. Percentage is relative to internal control Ul.

(ND) Not determined.

top of stem I, likewise has only a modest effect; because other mutants that disrupt the stem have relatively severe effects (see Fig. 2A), the $U_{27}: G_{38}$ base pair, if it exists, may contribute little to the stability of stem I. Finally, as expected from the behavior of the parental mutation $31 \mathrm{U}$, the double-point mutation $27 \mathrm{~A} / 31 \mathrm{U}$ also abolishes suppression.

\section{Mutations that inhibit suppression severely destabilize U1 snRNA}

As a first step toward understanding how mutations in stem-loop I of Ul-4u affect suppressor activity, we determined the level of suppressor U1-4u RNAs in transfected cells using a primer extension assay. We used a synthetic oligodeoxynucleotide primer complementary to nucleotides $8-23$ of $\mathrm{U} 1$ and performed a primer extension assay with the Klenow fragment of DNA polymerase I in the presence of dTTP, dCTP, and dATP. Klenow polymerase gives more faithful transcription than reverse transcriptase when one dNTP is omitted from the reaction (Zhuang and Weiner 1986). This assay allowed us to distinguish the suppressor U1-4u RNA from the endogenous $\mathrm{U} 1$ because the extension product for wild-type $\mathrm{Ul}$, which has a $\mathrm{C}$ residue at position 4 , will be 4 nucleotides shorter than that for Ul-4u in the absence of dGTP. To compare different U1-4u mutants, we cotransfected each of them with another Ul mutant as an internal control. The internal control U1 was made by replacing nucleotides 3 and 4 of U1 with a pentanucleotide sequence (GAAUU) that does not include a C residue. Thus, in the same primer extension assay, the extension product for the internal control U1 is $3 \mathrm{nu}$ cleotides longer than for U1-4u (Fig. 3; the major products for U1-4u and the internal control U1 are $1 \mathrm{nu}-$ cleotide shorter than expected, presumably because of the $5^{\prime}$-terminal cap structure).

Primer extension assays performed on some U1-4u mutants are shown in Figure 3 and summarized in Table 1. The parental U1-4u RNA is synthesized abundantly (Fig. 3, lanes 2 and 9) and, as observed previously, may represent as much as $25 \%$ of the total Ul in transfected cells (Zhuang and Weiner 1986). The internal control U1 is as abundant as U1-4u RNA. Mutations that have a severe effect on suppression also yield low levels of suppressor RNA (40U, 25A, 41C, 24A, 31U, and r28-31), 
Table 2. Phylogenetic comparison of the $5^{\prime}$ end and stem-loop I of U1 snRNA

\begin{tabular}{|c|c|c|c|c|c|c|}
\hline & $\begin{array}{l}5^{\prime} \text { Splice site } \\
\text { recognition }\end{array}$ & & $\begin{array}{l}\text { Stem I } \\
\left(5^{\prime} \text { half }\right)\end{array}$ & Loop I & $\begin{array}{l}\text { Stem I } \\
\left(3^{\prime} \text { half }\right)\end{array}$ & \\
\hline Human & AUACUUACCUG & GCAGG & GGAGAUEACCAU & GAUCACGAAG & GUGGUUUUCC & CAG \\
\hline Rat & ---------- & ----- & ----------- & ---------- & ---------- & --- \\
\hline \multicolumn{7}{|l|}{ Mouse } \\
\hline Ula & ----------- & ----- & ----------- & ---------- & ---------- & --- \\
\hline U1b-2 & ----------- & ----- & ----------- & $-----\mathrm{U}----$ & ---------- & --- \\
\hline U1b-5 & ----------- & ----- & ----------- & $----G-----$ & ---------- & --- \\
\hline Chicken & ----------- & ----- & $-----\underline{\mathrm{C}}-----$ & $-----\mathrm{G}-\mathrm{C}--$ & ---------- & --- \\
\hline Xenopus & $\begin{array}{l}----------- \\
-----------\end{array}$ & $\begin{array}{l}----- \\
-----\end{array}$ & $\begin{array}{l}-----ニ-ー-ー-- \\
-----------\end{array}$ & $\begin{array}{l}---------- \\
-----U----\end{array}$ & $\begin{array}{l}------\mathrm{C}--- \\
------\mathrm{C}---\end{array}$ & $\begin{array}{l}--- \\
---\end{array}$ \\
\hline Drosophila & ----------- & - - GUA & GA- GUUAA-- G- & ---------- & $-\mathrm{C}----\mathrm{CCU}-$ & $-G-$ \\
\hline Sea urchin & ----------- & $--\mathrm{GCA}$ & $--\mathrm{G}-\mathrm{U} \underline{C} G-\mathrm{AU}-$ & $-----\mathrm{A}----$ & - AU- CACC-- & --- \\
\hline Bean & ----------- & $-\mathrm{AC}--$ & -- UC- $-\underline{\mathrm{A}} \mathrm{UGG}--$ & ---- UAU--- & $--\mathrm{CCA}-\mathrm{GG}--$ & U- - \\
\hline Soybean & $\begin{array}{l}----------- \\
-----------\end{array}$ & $\begin{array}{l}-\mathrm{AC}-- \\
-\mathrm{AC}--\end{array}$ & $\begin{array}{l}-- \text { UC- } \overline{\text { A}} U G G-- \\
-- \text { UC- }- \text { A UGG - }\end{array}$ & $\begin{array}{l}-----\mathrm{A}---- \\
------\mathrm{U}---\end{array}$ & $\begin{array}{l}--\mathrm{CCA}-\mathrm{GG}-- \\
--\mathrm{CCA}-\mathrm{GG}--\end{array}$ & $\begin{array}{l}\text { U- - } \\
\text { U-- }\end{array}$ \\
\hline Green alga & ----------- & $\mathrm{U}-\mathrm{C}--$ & CCU $-\underline{C} \bar{G}--U C$ & $--G--A----$ & $-\mathrm{G}---\mathrm{C}-\mathrm{AGG}$ & U-- \\
\hline Yeast & $----------U$ & AAGAU & AUC- - - GG- & $-----\mathrm{A}----$ & - CC- $-\underline{\mathrm{A}}-\mathrm{GAU}$ & $--\mathrm{A}$ \\
\hline
\end{tabular}

The 5' cap nucleotide is not shown. $U$ residues at positions 5-6 are actually pseudouridines in some species. Only bases that differ from human U1 snRNA are indicated, and spaces are introduced into the sequence for comparison. The bulged nucleotides in the stem are underlined. Sequences for bean, soybean, yeast, and part of Xenopus U1 are derived from gene sequences. References for the U1 sequences are as follows: (Human) Branlant et al. (1980); (rat) Branlant et al. (1980); (mouse) Kato and Harada (1985); (chicken) Branlant et al. (1980); (Xenopus) Forbes et al. (1984); Zeller et al. (1984); Krol et al. (1985); (Drosophila) Mount and Steitz (1981); (sea urchin) Yu et al. (1986); (bean) van Santen and Spritz (1987); (soybean) van Santen et al. (1988); [green alga (Chlorella saccharophila)], Kiss et al. (1988); (yeast) Kretzner et al. (1987); Siliciano et al. (1987).

whereas mutations that have little effect on suppression produce high levels of suppressor RNA $(25 \mathrm{~A} / 40 \mathrm{U}, 33 \mathrm{~A}$, and $43 \mathrm{~A}$; although the unusual abundance of $25 \mathrm{~A} / 40 \mathrm{U}$ and $33 \mathrm{~A}$ could be real, it is likely to reflect the range of experimental error in a single data set). Because mutations within the U1-coding region do not appear to affect the efficiency of transcriptional initiation or 3 '-end formation (Skuzeski et al. 1984; Hernandez and Weiner 1986; Neuman de Vegvar et al. 1986; Hamm et al. 1987), we conclude that most mutations in stem-loop I that interfere with U1 suppressor activity do so by destabilizing U1 snRNA or the U1 snRNP.

\section{Severe mutations $25 \mathrm{~A}$ and $31 \mathrm{U}$ affect binding of $U 1$ snRNP-specific proteins}

Stem-loop I recently has been shown to be the binding site for the Ul snRNP-specific proteins (Hamm et al. 1987, 1988; Patton and Pederson 1988). Thus, it is possible that some mutations in stem-loop I of U1-4u may affect the binding of the U1-specific proteins in such a way that the RNA or RNP is degraded in vivo. To test this possibility, we performed an in vitro snRNP protein-binding assay. The Ul-4u gene, as well as two severe mutants $25 \mathrm{~A}$ and $31 \mathrm{U}$, were cloned into an SP6 vector to give in vitro transcripts that were 96 nucleotides long and included the U1-4u sequence from position 1 to 75 flanked by a few extra nucleotides at either end. The ability of these labeled SP6 RNAs to associate with Ul snRNP-specific proteins was analyzed by incubating the RNA in HeLa cell extracts and then immunoprecipitating with anti-(U1)RNP serum (Hamm et al.
1987; Patton et al. 1987). As an enriched source of snRNP proteins, we treated HeLa cell nuclear extract with micrococcal nuclease to digest the U-snRNAs and liberate free snRNP proteins, and inhibited micrococcal nuclease with EGTA to chelate calcium ions. Pretreatment with micrococcal nuclease increases the amount of U1-4u SP6 RNA that can be precipitated with anti-(U1)RNP serum from $<5 \%$ to $\sim 25 \%$ of the input RNA (Fig. 4A). When we tested U1-4u SP6 RNAs containing the second-site mutation $25 \mathrm{~A}$ or $31 \mathrm{U}$ (Fig. 4B), the mutant RNA was precipitated about fivefold less efficiently by anti-(U1)RNP serum than was the parental U1-4u SP6 RNA. We conclude that mutations 25A and $31 \mathrm{U}$ reduce the affinity of U1 snRNA for U1 snRNP-specific proteins.

Suppressor activity is reduced by insertions at position 11 of $U 1-4 u$

Nucleotides 3-11 at the $5^{\prime}$ end of U1 snRNA are exposed on the surface of the U1 snRNP (Lerner et al. 1980; Rinke et al. 1984) and are thought to form base pairs with the $5^{\prime}$ splice site (Lerner et al. 1980; Rogers and Wall 1980: Zhuang and Weiner 1986; Seraphin et al. 1988; Siliciano and Guthrie 1988). To test whether the position of $U 1$ nucleotides $3-11$ is rigidly specified relative to the body of the Ul snRNP, we inserted either one or two $\mathrm{G}$ residues at position 11 of U1-4u. These mutations, designated $+\mathrm{G}$ and $+\mathrm{GG}$, reduced suppressor activity to $\sim 34 \%$ and $24 \%$, respectively, as determined by the RNase protection assay (Fig. 5 and Table 1). We also determinec' the level of these two RNAs in transfected 


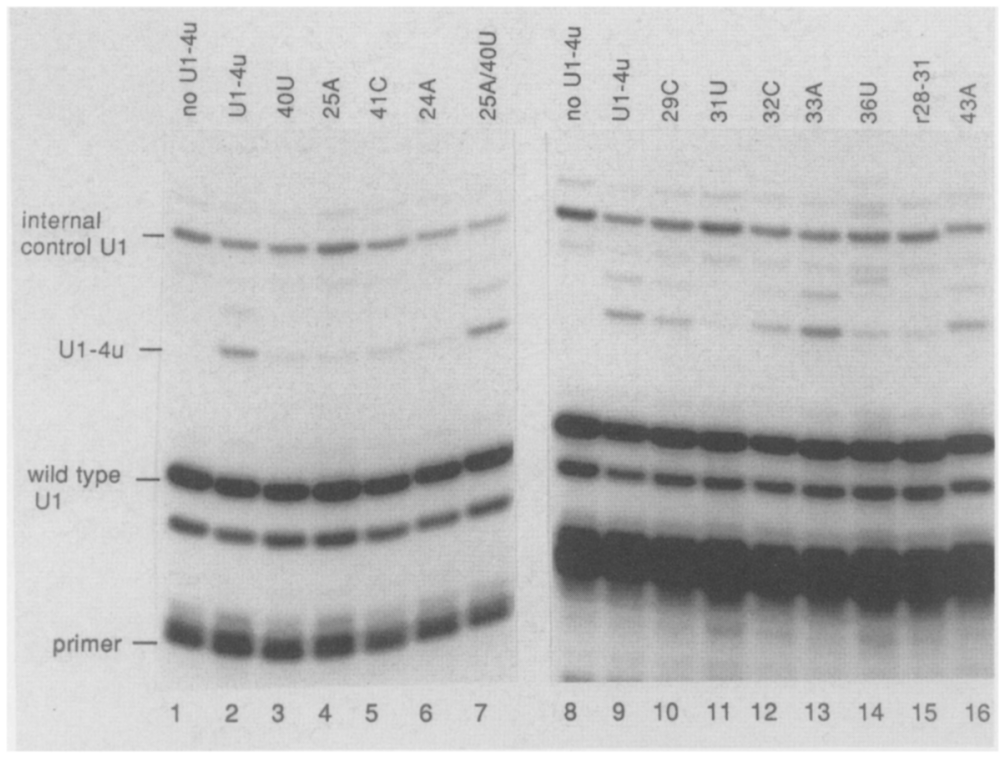

Figure 3. Expression of second-site mutants of $\mathrm{U} 1-4 \mathrm{u}$ in transfected cells, as determined by primer extension assay. HeLa cells were transfected with the adenovirus E1A hr440 mutant, different secondsite mutants in stem-loop I of Ul-4u, and an internal control U1 gene (see text). Using total RNA from transfected cells as template, an oligodeoxynucleotide complementary to nucleotides $8-23$ of U1 was used to prime DNA synthesis by the Klenow fragment of DNA polymerase I in the presence of dTTP, dCTP, and dATP. Extension products were resolved on a $15 \%$ denaturing polyacrylamide gel. The hr440 mutant and the internal control Ul gene were introduced into cells with pUC13 vector alone (lanes 1,8), the parental U1-4u gene (lanes 2,9), stem mutants (lanes $3-7,16$ ), or loop mutants (lanes $10-15)$.

cells by using a synthetic oligodeoxynucleotide complementary to nucleotides 17-46 of Ul to prime reverse transcriptase in the presence of all four deoxynucleoside triphosphates. The extension products for $+G$, + GG and the internal control U1 RNA will be longer than that for endogenous Ul by 1,2 , and 3 , nucleotides, respectively. As shown in Figure 6A, the $+\mathrm{G}$ and $+\mathrm{GG}$ RNAs are as abundant as the internal control $U 1$, which was shown above to be as abundant as U1-4u RNA (Fig. 3). The + G RNA can be immunoprecipitated by anti$\mathrm{Sm}$ and anti-(U1)RNP antibodies (Fig. 6B), indicating that it is assembled efficiently into a snRNP. Thus, the + G and + GG mutations appear to allow efficient assembly of a relatively inactive snRNP. This suggests, as might have been expected from phylogenetic evidence (see Table 2 below), that changes in the position of the $5^{\prime}$ end of U1 RNA relative to stem-loop I interfere with U1 snRNP function.

\section{Discussion}

\section{Functional aspects of the conserved U1 sequence}

We chose initially to make point mutations in stemloop I of U1 because the structure of this stem, the sequence of the loop, and the position of the stem-loop relative to the $5^{\prime}$ end of U1 snRNA have been highly conserved through evolution. We found that all three phylogenetically conserved features are important for the stability and/or function of U1 snRNA. As shown in Table 2, the base of stem-loop I is always found $16 \mathrm{nu}$ cleotides from the $5^{\prime}$ end of U1 snRNA. The loop contains 10 nucleotides (or 12 nucleotides if the base-pairing at the top of the stem does not exist), and the stem consists of 9 or $10 \mathrm{bp}$ interrupted by one or two bulged nucleotides. The sequence of the stem can vary, but most of the loop nucleotides are conserved.

Phylogenetic comparison suggests that the structure of the stem, but not the sequence, is important for func- tion (Fig. 2A). As expected, point mutations that weaken the stem weaken suppression (e.g., 25A or $40 \mathrm{U}$ ); compensatory base changes that restore the stem restore suppression $(25 \mathrm{~A} / 40 \mathrm{U})$; and substitution of a presumably stronger A : U base pair for the normal G : U base pair may even increase suppression (20A). Phylogenetically, the bulge in stem I can be U, C, A, or even two U residues, and we confirm this phylogenetic flexibility by showing that mutation of the bulged nucleotide from $U$ to $G(22 G)$ has little effect on suppression (we assume the mutation does not cause rearrangement of the basepaired stem). Mutation $38 \mathrm{U}$ might have been expected to disrupt a potential $\mathrm{U}_{27}: \mathrm{G}_{38}$ base pair at the top of stem I but has only modest effects compared to other mutants that disrupt the stem. Thus, the $U_{27}: G_{38}$ base pair may contribute little to the stability of stem I or may not exist at all (see also Kretzner et al. 1987).

Except for position 33, the loop sequence is highly but not absolutely conserved; all 4 bases can be found at position 33 , which is the only nucleotide in this loop that differs between human Ul and a variant mouse U1 (Kato and Harada 1985) or the U1 of Xenopus (Zeller et al. 1984), sea urchin (Yu et al. 1986), soybean (van Santen et al. 1988), and budding yeast (Kretzner et al. 1987; Siliciano et al. 1987). As expected on phylogenetic grounds, nucleotide 33 can be changed without significantly affecting suppression (Fig. 2B; mutants 33G and 33A). Also consistent with the phylogenetic data, increasing the size of the loop decreases suppression (mutant r28-31). Interestingly, although some mutations in highly conserved loop nucleotides have a severe effect on suppression (31U), others have less than a twofold effect (29C, 32C, 34U, 35U, 36U, and 38U). These data suggest that a twofold effect on function may be sufficient to fix the sequence of Ul snRNA on an evolutionary time scale. This observation is particularly interesting because human $\mathrm{Ul}$ is encoded by a large homogeneous multigene family whose copy number could, in principle, expand to compensate for deleterious muta- 


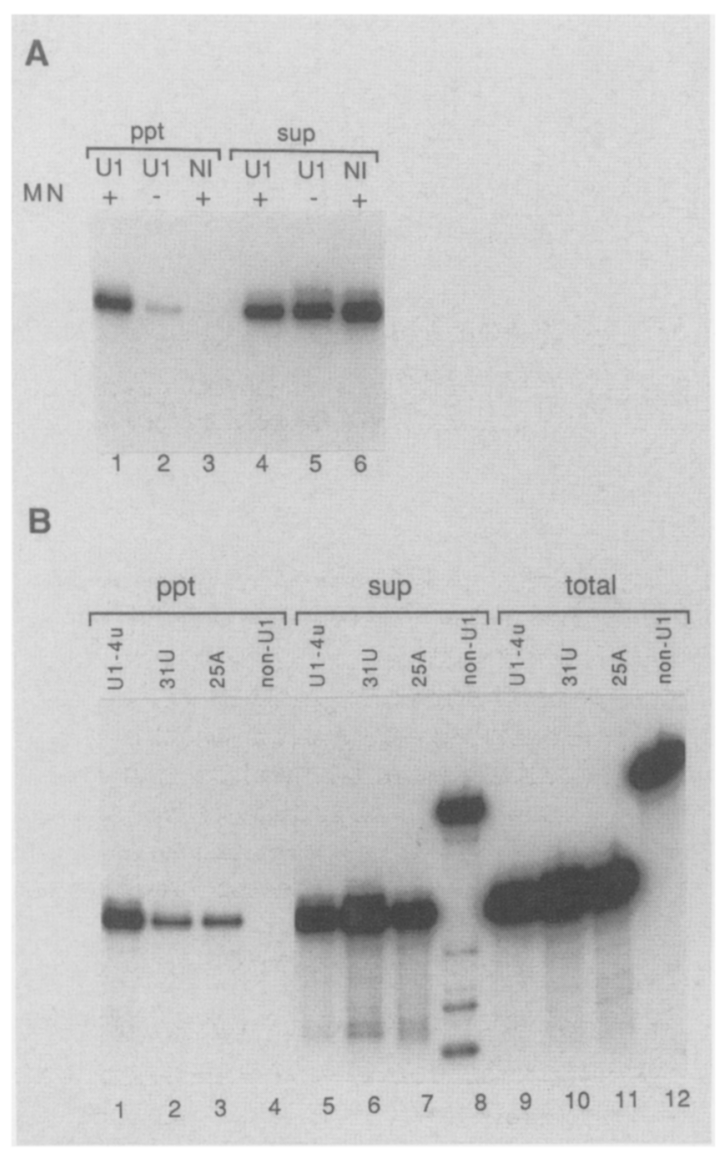

Figure 4. Effect of the $31 \mathrm{U}$ and $25 \mathrm{~A}$ mutations on binding of U1-specific proteins in vitro. $(A)$ A labeled SP6 transcript spanning nucleotides $1-75$ of U1-4u was incubated in a HeLa nuclear extract with $(+)$ or without $(-)$ prior treatment with micrococcal nuclease (MN) and then immunoprecipitated with anti-(U1)RNP serum (lanes U1) or nonimmune serum (lanes $N I$ ). RNA from precipitates (ppt) and supernatants (sup) was resolved on a $6 \%$ denaturing polyacrylamide gel. $(B)$ Labeled SP6 transcripts spanning nucleotides $1-75$ of $U 1-4 \mathrm{u}$ and the severe second-site mutants $31 \mathrm{U}$ and $25 \mathrm{~A}$ were incubated in HeLa nuclear extracts pretreated with micrococcal nuclease. Following immunoprecipitation with anti-(U1)RNP serum, total RNA (total), RNA from precipitates (ppt), and RNA from supernatants (sup) was resolved on a $6 \%$ denaturing polyacrylamide gel. Labeled SP6 transcripts span nucleotides $1-75$ or U1-4u (lanes $1,5,9)$, the second-site mutant $31 \mathrm{U}$ (lanes $2,6,10$ ), the secondsite mutant 25A (lanes $3,7,11$ ), or an unrelated RNA derived from the third exon of the rabbit $\beta$-globin gene, as described in Methods (lanes 4, 8, 12).

tions in the U1-coding region (Lund and Dahlberg 1984; Bernstein et al. 1985; Dahlberg and Lund 1988).

\section{Do mutations in stem-loop I affect U1 snRNP assembly or function?}

For all mutations tested in stem-loop I (Fig. 3), mutations that affect suppression severely lead to low levels of suppressor RNA, whereas mutations that have little effect on suppression produce high levels of suppressor

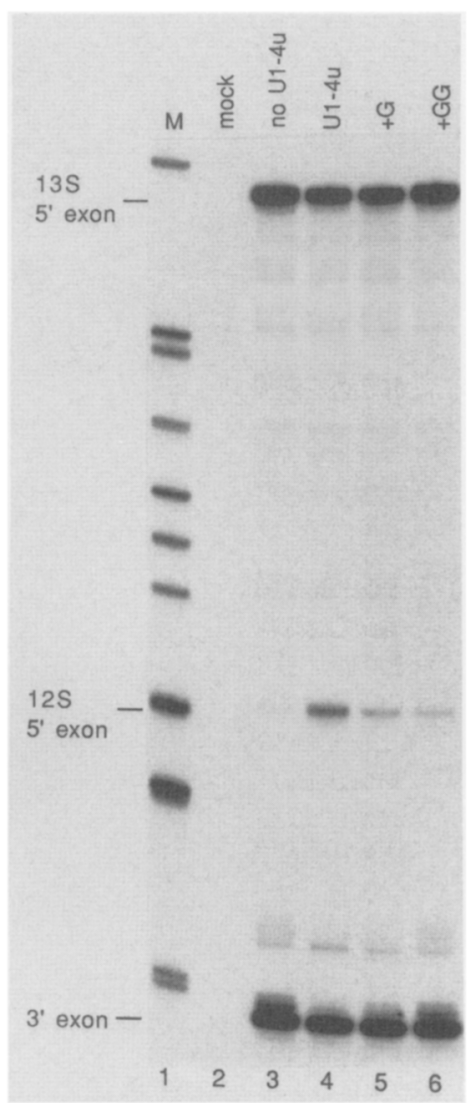

Figure 5. Effect of the mutations + G and + GG on suppression by U1-4u. HeLa cells were transfected with the E1A hr440 mutant and U1-4u mutant + G (lane 5) or + GG (lane 6). Cytoplasmic RNA from transfected cells was hybridized to an SP6 antisense transcript of the E1A hr440 gene (see Fig. 2C). The resulting hybrids were then digested with $\mathrm{T} 1$ and pancreatic RNase, and the products resolved on a $5 \%$ denaturing polyacrylamide gel. (Lane 3) Cells transfected with the hr440 mutant and pUC13 vector; (lane 4) cells transfected with the hr440 mutant and the U1-4u gene; (lane 2) mock-transfected cells; (lane 1) denatured DNA size markers from an end-labeled HpaII digest of pBR322.

RNA. The correlation between suppression and abundance suggests that mutations in stem-loop I usually interfere with suppressor activity by destabilizing U1 snRNA or the Ul snRNP. As a result, it is possible that many or all of the mutations we have characterized in stem-loop I affect the stability of U1 snRNA or the U1 snRNP rather than the ability of the mutant Ul snRNP to participate in splicing. In principle, the low levels of certain mutant U1 RNAs could also be explained by poor transcription; however, this would not explain the effect of the compensatory base change in stem I $(25 \mathrm{~A} / 40 \mathrm{U})$, and it also seems unlikely in light of evidence (Skuzeski et al. 1984; Hernandez and Weiner 1986; Neuman de Vegvar et al. 1986; Hamm et al. 1987) suggesting that mutations within the U1-coding region do not affect the efficiency of transcriptional initiation or $3^{\prime}$ end formation (for review, see Dahlberg and Lund 


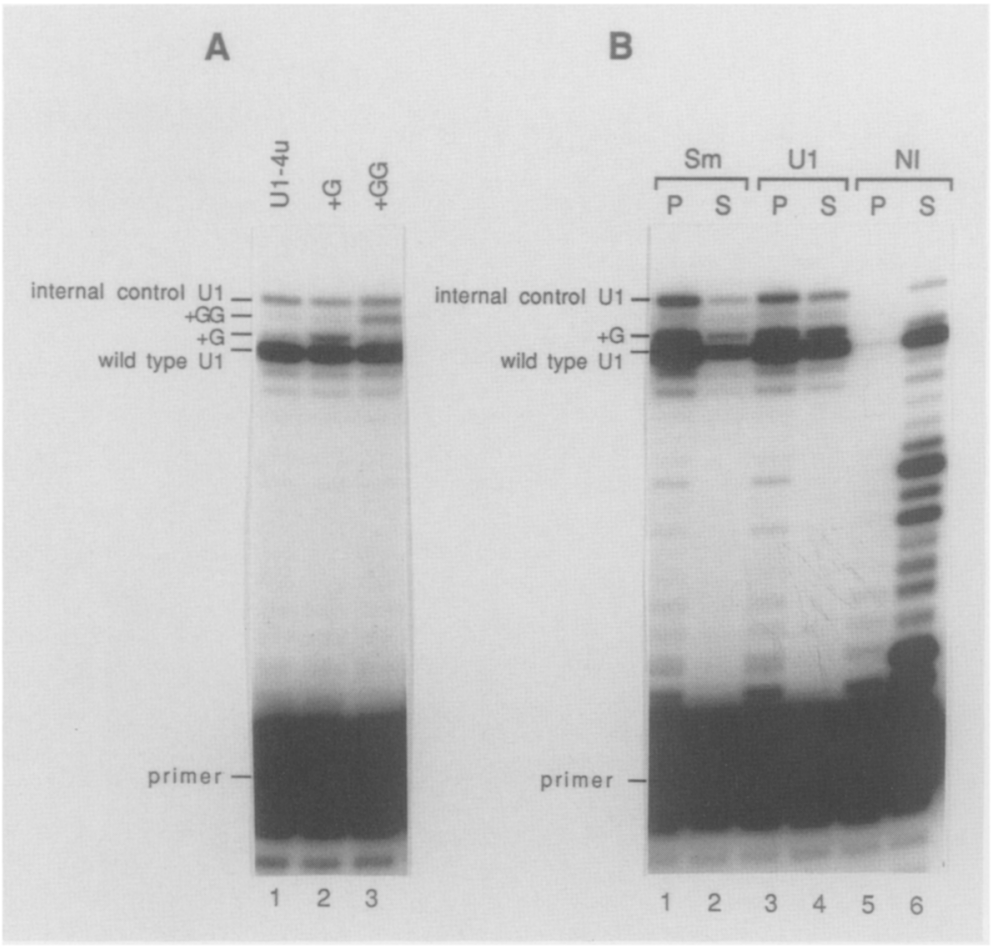

Figure 6. Expression of the $+\mathrm{G}$ and $+\mathrm{GG}$ mutants of U1-4u and immunoprecipitation of the +G RNA. (A) HeLa cells were transfected with the E1A hr440 mutant, the internal control Ul gene, and either the U1-4u gene (lane 1), the $+\mathrm{G}$ mutant (lane 2), or the + GG mutant (lane 3). Total RNA from transfected cells was hybridized to an oligodeoxynucleotide complementary to nucleotides $17-46$ or U1. The resulting hybrids were extended with reverse transcriptase in the presence of all four dNTPs and resolved on a $12 \%$ denaturing polyacrylamide gel. $(B)$ HeLa cells were transfected with the hr440 mutant, the internal control U1 gene, and the $+\mathrm{G}$ second-site mutant. Sonicates of transfected cells were immunoprecipitated with anti-Sm monoclonal antibody $(\mathrm{Sm})$, anti-(U1)RNP serum (U1), or nonimmune serum (NI). RNA from precipitates $(\mathrm{P})$ and supernatants $(\mathrm{S})$ was analyzed by primer extension as in $A$.

1988). In fact, mutant U1 RNAs with linker insertions at position 31 (which also duplicate nucleotides $28-31$, as in our mutation $\mathrm{r} 28-31$ ) have been shown previously to be unstable in HeLa cells with a half-life of only $1-2 \mathrm{hr}$ (Hernandez 1985) or expressed only at low levels in cultured rat cells (Watanabe and Oshima 1988). On the other hand, Hamm et al. (1987) have described mutant Xenopus U1 RNAs, including one that deletes stem-loop I, which appear to be stable in the Xenopus oocytes. This may imply that the pathways or parameters of RNA degradation in oocytes and cultured cells are different.

Stem-loop I is required for binding of the U1 snRNPspecific proteins 70K, A, and C (Hamm et al. 1987, 1988). We found that two severe mutations, stem mutation $25 \mathrm{~A}$ and loop mutation $31 \mathrm{U}$, reduce the ability of a U1 RNA fragment to associate with Ul-specific proteins in an in vitro binding assay (Fig. 4). Thus, it is possible that inefficient snRNP assembly may lead to degradation of the mutant snRNA in transfected cells. Perhaps degradation in vivo reflects competition between snRNP assembly and snRNA degradation, or competition between wild-type and mutant Ul RNA for a limited amount of the U1 snRNP-specific proteins (Mangin et al. 1985). Alternatively, mutant RNAs that can be precipitated in vitro by anti-(U1)RNP antibody may bind only one or two of the three Ul-specific proteins in vivo and therefore form unstable snRNPs. Subtleties such as these might also explain why mutations $25 \mathrm{~A}$ and $31 \mathrm{U}$ have similar effects on snRNP protein binding in vitro but slightly different effects on abundance and suppression in vivo.

\section{Effect of the extra nucleotides near the 5' end of U1}

Unlike mutations in stem-loop I, insertion of one or two $\mathrm{G}$ residues at position 11 decreases suppression (Fig. 5, mutants + G and +GG) without affecting the abundance of the snRNAs or their assembly into snRNPs, as judged by precipitation with anti-Sm and anti-(U1)RNP antibodies (Fig. 6). Although we cannot say with certainty how $+G$ and + GG affect splicing, phylogenetic conservation of the distance between the $5^{\prime}$ end of U1 and stem-loop I suggests that this spacing is important. Proper spacing might be required for binding of the Ul snRNP to the mRNA precursor and/or for correctly positioning the RNA duplex formed between the 5'-terminal sequence of $\mathrm{Ul}$ and the $5^{\prime}$ splice site (Zhuang and Weiner 1986; Seraphin et al. 1988; Siliciano et al. 1987), relative to the rest of the spliceosome so that the cleavage and ligation reactions can occur.

In conclusion, we have begun a second-site reversion analysis of mammalian U1 snRNA. We showed that a stable stem I structure and the conserved nucleotides within loop I are essential for U1 snRNA function. However, many mutations in stem-loop I were found to affect splicing indirectly by destabilizing Ul snRNA or affecting Ul snRNP assembly. Further analysis will be needed to identify U1 nucleotides that are directly involved in mRNA splicing. Ultimately, we hope to identify any U1 nucleotides that might base-pair with other snRNAs in the course of splicing and to test the nature of these interactions by making compensatory base changes in both snRNAs. 


\section{Methods}

\section{Mutant constructions}

The template for site-directed mutagenesis of U1-4u was an M13 mp8 clone containing the U1-4u gene as a 681-bp HaeIII fragment fitted with BamHI linkers (Zhuang and Weiner 1986). To make point mutations in stem-loop I of U1-4u, a mixed 30mer oligodeoxynucleotide complementary to positions 17-46 of $\mathrm{U} 1$ was synthesized so that each position was, on average, $97 \%$ wild type and $1 \%$ each of the other three nucleotides. Site-directed mutagenesis was performed as described (Kunkel 1985). Mutants were identified by dideoxy sequencing of single-stranded DNAs from the recombinant phage, using a primer complementary to positions $121-142$ of U1. Mutant U1-4u genes were recloned into the pUC13 vector as a HindIIIEcoRI fragment for use in transfection. Mutant 25A/40U was constructed by replacing the EcoRI-BclI fragment /extending from position -425 in $5^{\prime}$ flank to position 27 in U1-coding region) of mutant $40 \mathrm{U}$ in pUC13 with the corresponding fragment from mutant 25A. Mutant r28-31 was constructed by cutting the U1-4u gene in pUC13 at position 27 with BclI, filling the ends in with Klenow fragment, and religating. To make mutants + G, + GG, and internal control U1, site-directed mutagenesis was performed (as above) using the oligodeoxynucleotides 5'-TCTCCCCTGCCCAGGTAAATA-3', 5'-TCTCCCCTGCCCCAGGTAAATA-3', and 5'-TGCCAGGTAAAATTCATGAGATCTT-3', respectively.

To construct SP6 clones used in snRNP protein-binding experiments (Fig. 4), the BglII-BamHI fragments (extending from position -6 in $5^{\prime}$ flank to position +91 in $3^{\prime}$ flank) of the $\mathrm{U} 1-4 \mathrm{u}$ gene as well as mutants $25 \mathrm{~A}$ and $31 \mathrm{U}$, were isolated and cut at position 73 of the coding region with $H$ paII. The BglIIHpaII fragments were filled in with Klenow fragment and cloned between the filled-in HindIII and Sall sites of the vector pSP64 (Melton et al. 1984). The non-U1 SP6 clone was constructed by cloning a PvuII-BglII fragment of the rabbit $\beta$ globin gene (extending from position -9 in $5^{\prime}$ flank to position 1195 in exon 3) in opposite orientation between the BamHI and SmaI sites of the vector pSP64. DNA from this clone was linearized with EcoRI at position 1115 to give a 118-nucleotide transcript.

\section{Transfection and RNA preparation}

Transfections were performed as described previously (Hernandez 1985), using $6 \mu \mathrm{g}$ of the U1-4u gene in pUC13 and $6 \mu \mathrm{g}$ of plasmid pSVhr440 (Zhuang and Weiner 1986) per 6-cm plate. About $48 \mathrm{hr}$ after transfection, cytoplasmic RNA was extracted from the postnuclear supernatant of cells lysed with NP-40 (Hernandez 1985). In experiments comparing the abundance of various suppressor RNAs, HeLa cells were transfected with 4 $\mu \mathrm{g}$ each of the U1-4u genes, the internal control Ul gene, and pSVhr440. Total RNA was prepared from these cells lysed with SDS and proteinase $\mathrm{K}$. Following phenol-chloroform extractions, one volume of $95 \%$ ethanol was added and the resulting DNA clump was removed. Another volume of $95 \%$ ethanol was then added to precipitate the RNA.

\section{RNase protection analysis}

RNase mapping was performed essentially as described (Melton et al. 1984). RNase digestion was allowed to proceed for $30 \mathrm{~min}$ at $30^{\circ} \mathrm{C}$ and stopped with $2 \%$ SDS. The samples were then treated with $400 \mu \mathrm{g} / \mathrm{ml}$ of proteinase $\mathrm{K}$ at $37^{\circ} \mathrm{C}$ for $15 \mathrm{~min}$, extracted with phenol-chloroform, ethanol-precipitated, and fractionated on denaturing polyacrylamide gel.

\section{Primer extension}

Synthetic oligodeoxynucleotide primers were labeled at the $5^{\prime}$ end by kinasing. For mutants in stem-loop I of U1-4u, primer extension was performed with the Klenow fragment of DNA polymerase I at $37^{\circ} \mathrm{C}$ for $20 \mathrm{~min}$ in the presence of $38 \mu \mathrm{M}$ each of dTTP, dCTP, and dATP (Zhuang and Weiner 1986). For the $+\mathrm{G}$ and + GG mutants, primer extension was performed with reverse transcriptase as follows. RNA was mixed with the labeled primer in $12 \mu \mathrm{l}$ of $125 \mathrm{~mm} \mathrm{KCl}$ and $83 \mathrm{~mm}$ Tris- $\mathrm{HCl} / \mathrm{pH}$ 7.6), heated to $85^{\circ} \mathrm{C}$ for $2 \mathrm{~min}$, incubated at $65^{\circ} \mathrm{C}$ for $10 \mathrm{~min}$, and allowed to cool to room temperature for $30 \mathrm{~min}$. The mixture was made $3 \mathrm{~mm}$ in $\mathrm{MgCl}_{2}, 10 \mathrm{~mm}$ in DTT, $50 \mu \mathrm{g} / \mathrm{ml}$ in actinomycin D, and $0.5 \mathrm{mM}$ in each $\mathrm{dNTP} ; 200$ units of M-MLV reverse transcriptase (BRL) was added per 20- $\mu$ l reaction, and the reaction was incubated at $37^{\circ} \mathrm{C}$ for $1 \mathrm{hr}$. Reactions were stopped with $25 \mathrm{~mm}$ EDTA, ethanol-precipitated, and fractionated on a denaturing polyacrylamide gel.

\section{In vitro snRNP protein binding and immunoprecipitation}

HeLa cell nuclear extracts (Dignam et al. 1983) were made 1 $\mathrm{mM}$ in $\mathrm{CaCl}_{2}$, treated with $50 \mathrm{U} / \mu \mathrm{l}$ of micrococcal nuclease (Cooper Biomedical) at $37^{\circ} \mathrm{C}$ for $30 \mathrm{~min}$, and the reaction stopped with $5 \mathrm{~mm}$ EGTA. Labeled SP6 RNA of sp. act. $>10^{6}$ $\mathrm{cpm} / \mu \mathrm{g}$ was synthesized as described (Melton et al. 1984) and gel-purified. About $10^{5} \mathrm{cpm}$ of the SP6 RNA was incubated in a $15-\mu$ l reaction containing $60 \%$ (vol/vol) micrococcal nucleasetreated extract, $20 \mathrm{~mm}$ creatine phosphate, $0.5 \mathrm{mM} \mathrm{ATP}, 1 \mathrm{U} / \mu \mathrm{l}$ RNasin (Promega), and $1 \mu \mathrm{g} / \mu \mathrm{l}$ poly(A) (Sigma) at $37^{\circ} \mathrm{C}$ for 30 min. The reactions were then immunoprecipitated with anti-(U1)RNP serum (Pettersson et al. 1984), as described (Mimori et al. 1986). Assuming complete recovery of cellular U1 in the nuclear extract, there should be at least a fivefold excess of endogenous U1 snRNP proteins over added SP6 U1 transcripts under these assay conditions.

\section{Acknowledgments}

We thank Yuan Zhuang and Joan Steitz for helpful advice and materials. This research was supported by grant GM-31073-07 from the National Institutes of Health.

\section{References}

Bernstein, L.B., T. Manser, and A.M. Weiner. 1985. Human U1 small nuclear RNA genes: Extensive conservation of flanking sequences suggests cycles of gene amplification and transposition. Mol. Cell. Biol. 5: 2159-2171.

Black, D.L., B. Chabot, and J.A. Steitz. 1985. U2 as well as U1 small nuclear ribonucleoproteins are involved in premessenger RNA splicing. Cell 42: 737-750.

Branlant, C., A. Krol. J-P. Ebel, E. Lazar, H. Gallinaro, M. Jacob, J. Sri-Widada, and P. Jeanteur. 1980. Nucleotide sequence of nuclear U1A RNAs from chicken, rat and man. Nucleic Acids Res. 8: 4143-4154.

Brody, E. and J. Abelson. 1985. The 'spliceosome': Yeast premessenger RNA associates with a $40 \mathrm{~S}$ complex in a splicing-dependent reaction. Science 228: 963-966.

Chabot, B., D.L. Black, D.M. Lemaster, and J.A. Steitz. 1985. The $3^{\prime}$ splice site of pre-messenger RNA is recognized by a small nuclear ribonucleoprotein. Science 230: 1344-1349.

Dahlberg, J.E. and E. Lund. 1988. The genes and transcription of the major small nuclear RNAs. In Structure and function of major and minor snRNPs (ed. M.L. Birnstiel), pp. 38-70. Springer-Verlag, Heidelberg. 
Dignam, J.D., R.M. Lebovitz, and R.G. Roeder. 1983. Accurate transcription initiation by RNA polymerase II in a soluble extract from isolated mammalian nuclei. Nucleic Acids Res. 11: $1475-1489$.

Forbes, D.J., M.W. Kirschner, D. Caput, J.E. Dahlberg, and E. Lund. 1984. Differential expression of multiple U1 small nuclear RNAs in oocytes and embryos of Xenopus laevis. Cell 38: 681-689.

Frendewey, D. and W. Keller. 1985. Stepwise assembly of a premRNA splicing complex requires U-snRNPs and specific intron sequences. Cell 42: 355-367.

Gerke, V. and J.A. Steitz. 1986. A protein associated with small nuclear ribonucleoprotein particles recognizes the $3^{\prime}$ splice site of premessenger RNA. Cell 47: 973-984.

Grabowski, P.J., S.R. Seiler, and P.A. Sharp. 1985. A multicomponent complex is involved in the splicing of messenger RNA precursors. Cell 42: 345-353.

Green, M.R. 1986. Pre-mRNA splicing. Annu. Rev. Genet. 20: $671-708$.

Hamm, J., M. Kazmaier, and I.W. Mattaj. 1987. In vitro assembly of Ul snRNPs. EMBO I. 6: 3479-3485.

Hamm, I., V.L. van Santen, R.A. Spritz, and I.W. Mattaj. 1988. Loop I of U1 small nuclear RNA is the only essential RNA sequence for binding of specific Ul small nuclear ribonucleoprotein particle proteins. Mol. Cell. Biol. 8: 4787-4791.

Hernandez, N. 1985. Formation of the $3^{\prime}$ end of Ul snRNA is directed by a conserved sequence located downstream of the coding region. $E M B O J .4: 1827-1837$.

Hernandez, N. and A.M. Weiner. 1986. Formation of the $3^{\prime}$ end of U1 snRNA requires compatible snRNA promoter elements. Cell 47: 249-258.

Kato, N and F. Harada. 1985. New Ul RNA species found in Friend spleen focus forming virus-transformed mouse cells. J. Biol. Chem. 260: 7775-7782.

Kiss, T., M. Antal. H. Hegyi, and Solymosy. 1988. Plant small nuclear RNAs. IV. The structure of U1 RNA from Chlorella saccharophila: A phylogenetic support, in terms of RNA structure, for the probable interaction between U1 and U2 RNPs during the splicing of pre-mRNA. Nucleic Acids Res. 16: 2734

Kretzner, L., B.C. Rymond, and M. Rosbash. 1987. S. cerevisiae Ul RNAis large and has limited primary sequence homology to metazoan U1 snRNA. Cell 50: 593-602.

Krol, A., E. Lund, and J.E. Dahlberg. 1985. The two embryonic U1 RNA genes of Xenopus laevis have both common and gene-specific transcription signals. EMBO J. 4: 1529-1535.

Kunkel, T.A. 1985. Rapid and efficient site-specific mutagenesis without phenotypic selection. Proc. Natl. Acad. Sci. 82: $488-492$.

Lerner, M.R., J.A. Boyle, S.M. Mount, S.L. Wolin, and J.A. Steitz. 1980. Are snRNPs involved in splicing? Nature 283: $220-224$.

Lührmann, R. 1988. snRNP proteins. In Structure and function of major and minor snRNPs (ed. M.L. Birnstiel), pp. 71-99. Springer-Verlag, Heidelberg.

Lund, E. and J.E. Dahlberg. 1984. True genes for human U1 small nuclear RNA: copy number, polymorphism, and methylation. J. Biol. Chem. 259: 2013-2021.

Mangin, M., M. Ares, and A.M. Weiner. 1985. U1 small nuclear RNA genes are subject to dosage compensation in mouse cells. Science 229: 272-275.

Melton, D.A., P.A. Krieg, M.R. Rebagliati, T. Maniatis, K. Zinn, and M.R. Green. 1984. Efficient in vitro synthesis of biologically active RNA and RNA hybridization probes from plasmids containing a bacteriophage SP6 promoter. Nucleic Acids Res. 12: 7035-7056.
Mimori, T., J.A. Hardin, and J.A. Steitz. 1986. Characterization of the DNA-binding protein antigen $\mathrm{Ku}$ recognized by autoantibodies from patients with rheumatic disorders. J. Biol. Chem. 261: 2274-2278.

Mount, S.M. and J.A. Steitz. 1981. Sequence of U1 RNA from Drosophila melanogaster: Implications for U1 secondary structure and possible involvement in splicing. Nucleic Acids Res. 9: 6351-6368.

Mount, S.M., I. Pettersson, M. Hinterberger, A. Karmas, and J.A. Steitz. 1983. The U1 small nuclear RNA-protein complex selectively binds a $5^{\prime}$ splice site in vitro. Cell 33: 509518.

Neuman de Vegvar, H,E., E. Lund, and J.E. Dahlberg. 1986. 3' end formation of U1 snRNA precursors is coupled to transcription from snRNA promoters. Cell 47: 259-266.

Padgett, R.A., P.J. Grabowski, M:M. Konarska, S. Seiler, and P.A. Sharp. 1986. Splicing of messenger RNA precursors. Annu. Rev. Biochem. 55: 1119-1150.

Parker, R., P.G. Siliciano, and C. Guthrie. 1987. Recognition of the TACTAAC box during mRNA splicing in yeast involves base pairing to the U2-like snRNA. Cell 49: 229-239.

Patton, J.R. and T. Pederson. 1988. The $M_{r} 70,000$ protein of the U1 small nuclear ribonucleoprotein particle binds to the $5^{\prime}$ stem-loop of U1 RNA and interacts with Sm domain proteins. Proc. Natl. Acad. Sci. 85: 747-751.

Patton, J.R., R.J. Patterson, and T. Pederson. 1987. Reconstitution of the Ul small nuclear ribonucleoprotein particle. Mol. Cell. Biol. 7: 4030-4037.

Pettersson, I., M. Hinterberger, T. Minori, E. Gottlieb, and J.A. Steitz. 1984. The structure of mammalian small nuclear ribonucleoproteins. Identification of multiple protein components reactive with anti-(U1)ribonucleoprotein and anti-Sm autoantibodies. J. Biol. Chem. 259: 5907-5914.

Reddy, R. and H. Busch. 1988. Small nuclear RNAs: RNA sequences, structure, and modifications. In Structure and function of major and minor snRNPs (ed. M.L. Birnstiel), pp. 1-37. Springer-Verlag, Heidelberg.

Reddy, R., T.-S. Ro-Choi, D. Henning, and H. Busch. 1974. Primary sequence of U-1 nuclear ribonucleic acid of Novikoff hepatoma ascites cells. J. Biol. Chem. 249: 6486-6494.

Reed, R. and T. Maniatis. 1988. The role of the mammalian branchpoint sequence in pre-mRNA splicing. Genes Dev. 2: $1268-1276$.

Rinke, J., B. Appel, H. Blocker, R. Frank, and R. Lührmann. 1984. The 5'-terminal sequence of Ul RNA complementary to the consensus $5^{\prime}$ splice site of hnRNA is single-stranded in intact U1 snRNP particles. Nucleic Acids Res. 12: 41114126.

Rogers, J. and R. Wall. 1980. A mechanism for RNA splicing. Proc. Nat1. Acad. Sci. 77: 1877-1879.

Ruskin, B., P.D. Zamore, and M.R. Green. 1988. A factor, $\mathrm{U} 2 \mathrm{AF}$, is required for $\mathrm{U} 2$ snRNP binding and splicing complex assembly. Cell 52: 207-219.

Seraphin, B., L. Kretzner, and M. Rosbash. 1988. A U1 snRNA : pre-mRNA base pairing interaction is required early in yeast spliceosome assembly but does not uniquely define the 5' cleavage site. EMBO I. 7: 2533-2538.

Siliciano, R.G. and C. Guthrie. 1988. 5' splice site selection in yeast: Genetic alterations in base-pairing with U1 reveal additional requirements. Genes Dev. 2: 1258-1267.

Siliciano, P.G., M.H. Jones, and C. Guthrie. 1987. Saccharomyces cerevisiae has a U1-like small nuclear RNA with unexpected properties. Science 237: 1484-1487.

Skuzeski, J.M., E. Lund, J.T. Murphy, T.H. Steinberg, R. R. Burgess, and J.E. Dahlberg. 1984. Synthesis of human U1 RNA II. Identification of two regions of the promoter essential for 
transcription initiation at position +1 . I. Biol. Chem. 259: 8345-8352.

Steitz, J.A., D.L. Black, V. Gerke, K. Parker, A. Krämer, D. Frendewey, and W. Keller. 1988. Functions of abundant UsnRNPs. In Structure and function of major and minor snRNPs (ed. M.L. Birnstiel), pp. 115-154. Springer-Verlag, Heidelberg.

Swanson, M.S. and G. Dreyfuss. 1988. RNA binding specificity of hnRNP proteins: A subset bind to the $3^{\prime}$ end of introns. EMBO I. 7: 3519-3529.

Tazi, J., C. Alibert, J. Temsamani, I. Reveillaud, G. Cathala, C. Brunel, and P. Jeanteur. 1986. A protein that specifically recognizes the $3^{\prime}$ splice site of mammalian pre-mRNA introns is associated with a small nuclear ribonucleoprotein. Cell 47: $755-766$.

van Santen, V.L. and R.A. Spritz. 1987. Nucleotide sequence of a bean (Phaseolus vulgaris) Ul small nuclear RNA gene: Implications for plant pre-mRNA splicing. Proc. Natl. Acad. Sci. 84: 9094-9098.

van Santen, V.L., W. Swain, and R.A. Spritz. 1988. Nucleotide sequences of two soybean U1 snRNA genes. Nucleic Acids Res. 16: 4176.

Watanabe, N. and Y. Oshima. 1988. Three types of rat U1 small nuclear RNA genes with different flanking sequences are induced to express in vivo. Eur. J. Biochem. 174: 125-132.

Yu, J.-C., M.A. Nash, C. Santiago, and W.F. Marzluff. 1986. Structure and expression of a second sea urchin gene repeat. Nucleic Acids Res. 14: 9977-9988.

Zeller, R., M.T. Carri, I.W. Mattaj, and E.M. De Robertis. 1984. Xenopus laevis U1 snRNA genes: Characterization of transcriptionally active genes reveals major and minor repeated gene families. $E M B O$ J. 3: 1075-1081.

Zhuang, Y. and A.M. Weiner. 1986. A compensatory base change in Ul snRNA suppresses a 5 ' splice site mutation. Cell 46: 827-835.

Zhuang, Y., A.M. Goldstein, and A.M. Weiner. 1989. UACUAAC is the preferred branch site for mammalian mRNA splicing. Proc. Natl. Acad. Sci. 86: 2752-2756. 


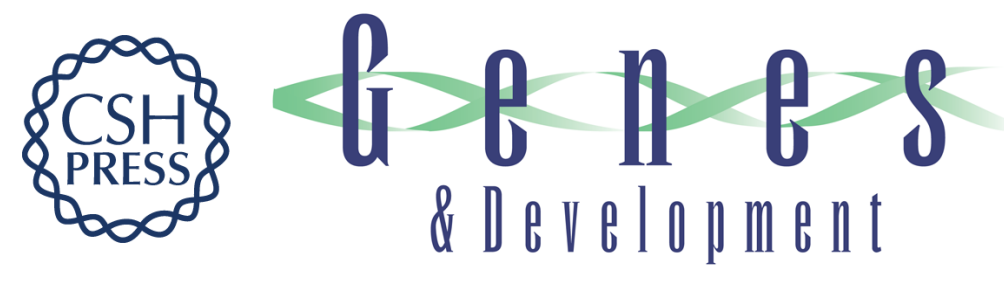

\section{Genetic analysis of the role of human U1 snRNA in mRNA splicing: I. Effect of mutations in the highly conserved stem-loop I of U1.}

C Y Yuo and A M Weiner

Genes Dev. 1989, 3:

Access the most recent version at doi:10.1101/gad.3.5.697

\section{References This article cites 51 articles, 20 of which can be accessed free at: http://genesdev.cshlp.org/content/3/5/697.full.html\#ref-list-1}

\section{License}

Email Alerting

Receive free email alerts when new articles cite this article - sign up in the box at the top Service right corner of the article or click here.

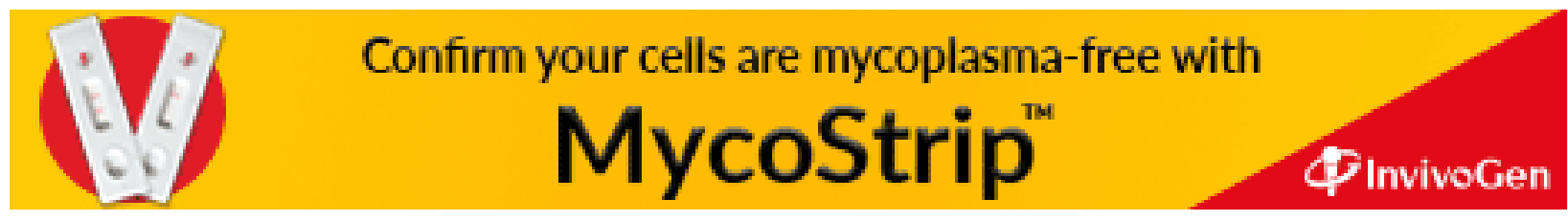

